\title{
Перевезенцева Ю.В. \\ «Долой Христа», или Богоборческий мотив в сборнике «Еgo sum qui sum» Александра Тинякова
}

Калужский государственный университет им. К. Э. Циолковского

doi: 10.18411/lj-05-2021-277

(Россия, Калуга)

\section{Аннотация}

В данной статье проведен анализ богоборческого мотива в сборнике «Ego sum qui sum» А. И. Тинякова - русского поэта Серебряного века.

Ключевые слова: богоборческий мотив, Тиняков, 20 век.

\section{Abstract}

This article analyzes the God-fighting motif in the collection «Ego sum qui sum» by A. I. Tinyakov - a russian poet of the Silver Age.

Keywords: God-fighting motif, Tinyakov, 20th century.

Тема богоборчества была популярна в русской литературе XX века - ею интересовались классики и поэты декадентской волны [3]. Богоборческие идеи довольно тесно связаны с учением Ф. Ницше, который в своем трактате «Так говорил Заратустра» писал: «Умерли все боги; теперь мы хотим, чтобы жил сверхчеловек» [1, 57]. Но нельзя утверждать, что только на идее о сверхчеловеке строилась богоборческая тема в русской литературе, можно даже сказать, что в своих роптаниях поэты или писатели не утверждают, что «Бог умер», а скорее признают его существование, но корят или даже ненавидят за определенные деяния или, наоборот, бездействие. Такой позиции придерживался и поэт Александр Иванович Тиняков.

Сборник «Ego sum qui sum» («Аз, есмь сущий») - вершина творчества Тинякова. Каждое стихотворение здесь является демонстрацией всего безобразного, порочного и эгоистичного, что может быть в человеке, отражением психологии кутилы и распутника, с восторгом рассказывающего о своих похождениях. Этот образ отвергает любую мораль, нравственность и веру в Бога как проявление общественных норм поведения и жизни в целом. В данной работе мы рассмотрим богоборческий мотив, преобладающий в стихотворениях, посвященных образу гуляки.

Палестинский пигмей худосочный,

Надоел нам жестоко Христос,

Радость жизни он сделал непрочной,

Весть об аде он людям принес.

Но довольно возиться с распятым

И пора уж сказать: он - не бог;

Он родился и вырос проклятым,

По-людски веселиться не мог.

И без дела бродил по дорогам,

И в душе был мертвей мертвеца,

И, ютясь по глухим синагогам,

Проповедовал близость конца.

В наше время его б посадили

К сумасшедшим, за крепкую дверь,

Ибо верно б теперь рассудили,

Что он был вырожденец и зверь. 
Но тогда его глупые речи

И запачканный, рваный хитон

Поражали сильнее картечи

Истеричных подростков и жен.

И хоть взял его царственный Ирод,

И распял его мудрый Пилат,

Все же был им в сознании вырыт

Отвратительный, мерзостный ад.

Но довольно садиста мы чтили,

Много крови он выпил, вампир!

Догнивай же в безвестной могиле, -

Без тебя будет радостней Мир [2]! -

В данном стихотворении с призывающим названием «Долой Христа!» герой обвиняет Христа в том, что тот дал людям понятие духовности, праведности; корит его за знание об «отвратительном, мерзостном» аде, который якобы не дает теперь людям в полной мере использовать «радости жизни»: «Радость жизни он сделал порочной, Весть об аде он людям принес» [2]. Обратив внимание на другие стихотворения третьего сборника, мы сможем понять, что герой, типичный для позднего творчества Тинякова, считает естественными радостями жизни сытость, сексуальное удовлетворение и другие плотские потребности, которые считаются в религии греховными (прелюбодеяние, чревоугодие и др.).

Христос зовется своим именем в данном стихотворении всего один раз, в самом начале, далее герой дает ему уничижительные прозвища: «палестинский пигмей», «распятый», «вырожденец и зверь», «садист», «вампир». Во многом это связано с тем, что герой считает Христа глупцом («... его глупые речи...» [2]). Мудрым же он зовет не человека разумного, нравственного, знающего и понимающего, а пьяницу или гуляку, идущего по всевозможным путям телесного удовольствия; и проблему Христа он видит в том, что тот «По-людски веселиться не мог». Так, в стихотворении «Без морали» (1922) герой называет глупцом человека, задумывающегося о смысле жизни; а

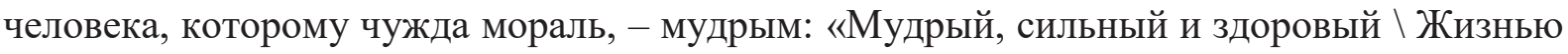
пьян, как от вина» [2]. Мораль он напрямую связывает с духом Христа, как его проявлением:

Все, в чем есть морали привкус,

Мне противно и смешно

И гнилым Христовым духом

Для меня осквернено [2].

Здесь также герой нелестно характеризует Христа, называя его «гнилым».

В стихотворении «Я гуляю!» (1922) также прослеживается тенденция отказа от нравственности и духовности, так, герой призывает ангелов - духовных существ - пить коньяк:

Кто назвал разгул позором?

Думать надо, что - дурак!

Пойте, девки, песни хором,

Пейте, ангелы, коньяк [2]! 
Также в этих строках можно заметить намек на смену ролей: разгульные девки вместо питья алкоголя поют хоровую песню, а ангелы вместо хорового пения - пьют. Возможно, что слово «ангелы» здесь используется в роли обращения, выступая неким синонимом к слову «девки», что несет парадоксальную идею - ангелы не безгрешны.

В самом известном стихотворении А. И. Тинякова «Моление о пище» (1921) также можно заметить богоборческий мотив. Здесь лирический герой ставит потребность в пище выше веры в Бога и в Рай, ради куска «гнилой трески» он готов отречься от Рая и добровольно «полезть» в Ад:

За кусок конины с хлебом

Иль за фунт гнилой трески

Я, - порвав все связи с небом, -

В ад полезу в батраки [2].

В стихотворении «За веком век Христовы слуги...» (1921) мы видим прямое отречение от заветов Христа, от морали: «Я их заветы отвергаю» [2]. Герой уверяет, что, несмотря на свой разгульный образ жизни, на равнодушие к понятиям добра и зла, он счастлив даже в своих горестях:

Я их заветы отвергаю.

Добра от зла не отличаю, -

И все ж я, несомненно, жив

И даже весело играю,

И даже в горестях счастлив [2].

Герой пытается донести до читателя, что необязательно следовать божьей морали, трепетать перед Страшным судом, чтобы чувствовать себя полноценным и счастливым; он верит, что душа человека не поддается измерению со стороны только добра или только зла. Для героя все равны - независимо от поступков и жизненной позиции. Так, он говорит, что после смерти одинаково отнесется и к святому, и к убийце: «Святому жму я крепко руку, \Убийце руку крепко жму» [2].

Что интересно, во всех стихотворениях, включая и «Долой Христа!» (1922), автор пишет слово «бог» с маленькой буквы, а вот слово «Мир» с большой - такой графический прием помогает понять позицию героя.

Тиняков сумел наиболее точно передать настроение богоборца, во многом благодаря иронии, доводящей позицию героя до абсурда. Он будто насмехается над этим пьяницей, не видящим ничего, кроме алкоголя и разгульных девок в кабаке.

Богоборческий мотив в сборнике «Ego sum qui sum» зиждется на разочарованности, неуверенности и непринятии религиозных, следовательно и нравственных, принципов. Герой ищет способ жизненного удовлетворения в плотский радостях, а не в духовности, стирает границы между добром и злом (это иллюстрируется в стихотворении «За веком век Христовы слуги...» словами: «Добра от зла не отличаю» [2]) через пропаганду «разгульного» образа жизни, так как для него Бог безмолвствует либо не замечает людских страданий; а Христос принес человечеству знание об этом самом молчащем Боге, знание о Страшном суде, который определит участь каждого человека по его грехам. Отсюда появляется и осуждение людей, следующих нормам морали. Герой считает, что они лишь трепещут перед Богом, а не искренне следуют его заповедям, потому и не идут по пути наслаждения, лицемерно осуждая гуляк, берущих, по мнению героя, от жизни все, что только могут.

$$
* * *
$$

1. Ницше Ф. Так говорил Заратустра. - СПб.: Вита Нова, 2012. - 448 с. 
2. Тиняков А. И. Ego sum qui sum. Третья книга стихов. 1921 - 1922 гг. [Электронный ресурс]. Режим доступа: https://viewer.rusneb.ru/ru/000200_000018_RU_NLR_DIGIT_132454?page=1\&rotate=0\&theme=white (дата обращения: 24.04.2021).

3. Хетагурова Д. К. Трансформация богоборческих мотивов в поэзии символизма (К. Д. Бальмонт, Ф. К. Сологуб, А. И. Токаев). [Электронный ресурс]. - Режим доступа: https://cyberleninka.ru/article/n/transformatsiya-bogoborcheskih-motivov-v-poezii-simvolizma-k-dbalmont-f-k-sologub-a-i-tokaev/viewer (дата обращения: 24.04.2021).

\section{Поштанова М.С., Овшиева Н.Л. \\ Прагматика вербальной иронии в англоязычном коротком рассказе \\ ФГБОУ ВО Калмыцикий государственныцй университет им. Б.Б. Городовикова} (Россия, Элиста)

doi: 10.18411/lj-05-2021-278

\section{Аннотация}

В статье вербальная ирония рассматривается с позиций Неограйсовской теории разговора и теории Д. Уилсон и Д. Спербера. Выявляются наиболее частотные случаи вербальной иронии в литературном дискурсе, а также их функции.

Ключевые слова: ирония, прагматика, импликатура, теория Грайса, теория релевантности, литературный дискурс

\section{Abstract}

The article examines verbal irony from a neo-Gricean perspective of conversation and theory by D. Wilson and D. Sperber. The most frequent cases of verbal irony are revealed, as well as their functions in literary discourse.

Keywords: irony, pragmatics, implicature, Gricean approach, Relevance theory, literary discourse

Вербальная ирония долгое время изучалась как художественный троп в различных типах литературного дискурса, однако сейчас среди исследователей прослеживается тенденция к уходу от традиционного понимания иронии. Утверждается, что ирония - это нечто большее, чем просто литературный прием, это образ мышления, стратегия ведения диалога, которая помогает говорящему более эффективно достигать своих целей в коммуникации. Этим новым осмыслением объясняется изучение иронии на современном этапе с точки зрения прагматики.

Прагматика, как наука о функционировании языковых знаков в рамках определенной ситуации, стремится установить интенции говорящего, использующего иронию, а также принципы ее функционирования в дискурсе. В разное время ирония в прагматике рассматривалась как притворство, эхо, аллюзия и значимая неуместность, однако впервые этот прием определил с позиции прагматики П. Грайс как конверсационную импликатуру. По мнению лингвиста, ирония характеризуется нарушением максимы качества, которая является одной из четырех максим в принципе кооперации Грайса, и выведением оценочной импликатуры [4]. И хотя это понимание иронии подвергалось не раз критике, оно не утратило актуальности. Сегодня некоторые исследователи, используя идеи Грайса как базис, модифицируют их и, внося необходимые дополнения, говорят о новом Неограйсовском подходе к вербальной иронии.

Одним из таких последователей Грайса является М. Динел, которая доказывает несостоятельность критических замечаний в адрес подхода Грайса и, опираясь на его положение о том, что ирония основана на противопоставлении либо отрицании, выделяет два основных типа вербальной иронии: иронию, основанную на отрицании пропозиции (propositional negation irony), и иронию, основанную на 